\title{
SOCIAL AND POLITICAL ASPECTS OF THE DEVELOPMENT OF CYCLING IN POMORZE ZACHODNIE (WEST POMERANIA) IN THE YEARS 1945-1950
}

\author{
Ryszard Stefanik, A, B, D Maciej ZawadzkiB, D \\ University of Szczecin, Faculty of Health and Physical Education, Poland

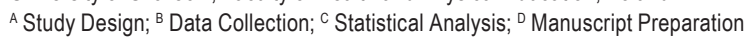 \\ Address for correspondence: \\ Ryszard Stefanik \\ Wiosny Ludów 24/67, 71-471 Szczecin, Poland \\ E-mail: ryszard.stefanik@usz.edu.pl
}

\begin{abstract}
The article presents the determinants of the development of cycling in the areas incorporated by Poland in the first years after the Second World War.

The biggest contribution into this process was made by people from large cities, pre-war enthusiasts and athletes who undertook the hardships of social activity and the engagement of local youth. Sports organizations were controlled, but also supported, by state authorities that used mass events in the propaganda policy and actions aimed at integrating the Northern and Western Lands with the rest of the country. This was an important task due to the difficult living conditions and marauding groups of criminals for whom Pomorze Zachodnie constituted an area of criminal activity, mainly plundering former German property, as well as attacking. Polish settlers. The development of cycling in Szczecin was favored by the German infrastructure, including a concrete track often used in national championships.

At the end of 1949, sport in Poland was reorganized and centralized, making it similar to the Soviet model, where there was no room for social measures. The bourgeoisie clubs had to cease their activities, while the circles and clubs were created at workplaces and trade unions. Sports federations were liquidated and their place was occupied by sports clubs located within the structures of the state administration. The organizational changes were accompanied by the mass popularization of sport and increased financing for competitive sport from the state budget. The goal of such activities was to reach a wide group of young people for the needs of indoctrination, as well as to raise the level of sport to achieve more effective competition with Western countries.
\end{abstract}

Key Wordls sport history, years 1945-1950, physical culture

\section{Introduction}

With the end of the Second World War, the communists took over power in the area of Poland occupied by the Soviet army. They were protected by the former occupant, and later the Allies' supporter, as well as reinforced by the armed units of the Internal Security Corps (ISC) the Office of Public Security (OPS). During the chaos, it was difficult to control society to a full extent and counteract the spontaneous movement of the population. One of the directions of intersecting roads was Pomorze Zachodnie, in the past called Hinterpommern (Farther Pomerania). This was 
not due to the proper conditions of settlement, but its closeness to Western Europe. There was a transport route stretching from Szczecin to Berlin, and further to the zone of capitalist countries. It was not without reason that all of Pomorze Zachodnie was called "the Wild West". The plundering of post-German property by Soviet soldiers, but also the Poles themselves, discouraged people from settling. Especially that in the "rage" of the so-called looting, defenseless civilians were often assaulted.

In the atmosphere of post-war demoralization and general vagrancy, sport activists and athletes themselves were a positively distinguished group. Of course, the years of occupation had to affect them negatively, which was also noticeable in brutal and particularly aggressive field behavior. However, when most of the Poles arriving to the Western and Northern Lands were busy with their own problems, i.e. looking for a place to live, food and work, those with passion and commitment started to create sports clubs, organize training and first competitions, especially football matches. Another activity preferred by the settlers was cycling, despite the lack of proper equipment at that time.

So far, there has been no reliable and critical study on cycling in Pomorze Zachodnie after 1945. Therefore, the authors undertook the task of examining the social and political conditions that influenced the development of this sport discipline in the territory incorporated by Poland after the Second World War. This article is also a preliminary study of the formation of cycling in the period of pioneer settlement and the reconstruction of sports activities based on the pre-war model.

The research involved an analysis of archival and press materials as well as literature on the subject applying the inductive method. Furthermore, conclusions were drawn without the possibility of direct access to relevant materials, as well as based on knowledge beyond the source (the method of deduction). Materials collected in the State Archive in Szczecin, the Faculty of Health and Physical Education of University of Szczecin as well as private collections were used.

\section{Results of the research}

Although in autumn 1945 cycling competitions had not yet been organized, a group of post-war enthusiasts of this sports discipline already existed in Szczecin. The problem constituted a lack of both active athletes and bicycles, which were considered luxury goods at that time, with every person using such means of transport being exposed to assaults and robberies. In the following years, brutal attacks on officials, teachers or postal workers cycling to work were not uncommon. Nevertheless, a favorable element was the infrastructure: high-class road surfaces, highways, the motorway outside Szczecin, not to mention the concrete cycling track in Szczecin itself.

In the first place, Pomorze Zachodnie was inhabited by people coming from the closest Wielkopolska and the destroyed Warsaw, as well as forced laborers returning to their homeland and prisoners of war. Szczecin welcomed a lot of citizens of Poznań, who were usually sent there by the authorities to organize public administration and municipal services. It was this group coming from metropolitan areas that shaped the development of sport on the so-called "Recovered Territories", though de facto they were acquired lands. For many settlers-athletes coming to these areas meant new career opportunities. Of course, this was usually associated with the need to join the Polish Workers' Party (PPR), and from 1948 - the Polish United Workers' Party (PUWP). However, most activists did not protest against such attitudes. It was possible to treat such behaviors as a kind of camouflage donned every day during German occupation. 
The first sports club, which associated mainly employees of the city council, was established in Szczecin on July 20,1945, and took the name "Odra", referring to the border river flowing through the city. It was a common geographical motif used by sports communities, however in the post-war times, when the border changed, it took on a special propaganda meaning. The association also became the nucleus of the growing cycling culture since the spring of 1946, when a specialized unit was established ("Kurier Szczeciński", 1946, No. 62). It brought together cycling activists and enthusiasts of this discipline: Leon Bestry and Dominik Nadolski, with the latter being an owner of a workshop and bicycle shop. They were supported by Jan Dix, a sports activist, athlete, referee and football coach (the State Archive in Szczecin - APSz, the City Board and National City Council - ZMiMRN in Szczecin, file number 240, "Odra" Sports Club, 1945-1949, p. 27).

The first chance to demonstrate sports activity was a propaganda event organized by the central authorities called "Trzymamy straż nad Odra" ("We Keep Guard Over the Oder"), as part of the National Youth Meeting (April 12-14, 1946). Among the guests invited to Szczecin there were Bolesław Bierut, Edward Osóbka-Morawski, Michał Żymierski-Rola and Stanisław Mikołajczyk. The program of the ceremony included the Recovered Territories Games with a cycling competition (APSz, ZMiMRN in Szczecin, file number 520, Report on the activities of the City Committee of Physical Education and Military Training in Szczecin, pp. 1-2; "Kurier Szczeciński", 1946, No. 72, 75, 81, 85). Although there were not cyclists from Szczecin, the competition took place with the participation of leading sportsmen from other regions of the country. On April 14, 1946, the first road race along the 60-km long PolishGerman border (26 competitors) was organized in Pomorze Zachodnie, and on the following day - the competition on a concrete track with the participation of 21 cyclists took place (Tuszyński, 1986; "Kurier Szczeciński", 1946, No. 85 ). The above-mentioned event served propaganda to be sure, but at the same time contributed to the popularization of this discipline in Szczecin. Competitions on the cycle track were able to attract from several up to 10,000 spectators. That is why the municipal and voivodeship authorities started supporting the organization of mass events and the renovation of the former German building. However, there was still a lack of appropriate equipment, mainly bikes, which is why only a few people wanted to become a member of the cycling unit during that time. The training itself was usually trips to suburban villages.

Another breakthrough moment in cycling in Zachodniopomorskie voivodeship took place in July 1946, when the Regional Cycling Federation (OZKol.) was established in Szczecin. It was, in fact, created by the same activists from the "Odra" Sports Club, joined by Roman Antowski, who came from Poznań. Leon Bestry was chosen the President of OZKol. The first and at the beginning the only federation member was the "Odry" cycling unit (APSz, PWRN in Szczecin, file number 11477, Minutes of OZKol.'s meetings, 1946-1949, p. 5). The main objective of the activists was the organization of the first local races. However, there was still the problem of the lack of willing and active participants. For these reasons, the event had to be postponed twice. It was possible to carry out $15-\mathrm{km}$ long competitions around Jasne Błonia in Szczecin as late as in August. The race was won by Hieronim Machnik from "Odra" Sports Club, who was rewarded a camera funded by the Governor of Szczecin - Lt. Col. Leonard Borkowicz (“Kurier Szczeciński”, 1946, No. 184). 


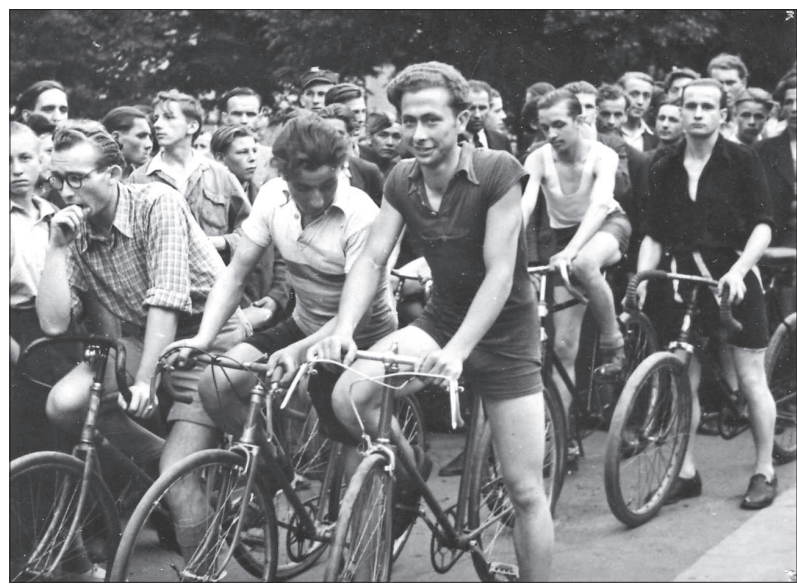

Figure 1. Before the start of the race around Jasne Błonia on August 11, 1946

Source: Collections of the Faculty of Health and Physical Education of University of Szczecin (WKFiZ US).

Nevertheless, the biggest event in Szczecin in 1946 was the September 50t ${ }^{\text {t }}$ Polish cycling championship at a distance of $50 \mathrm{~km}$ won by Jerzy Bek. This event was also included in the policy of integrating Recovered Territories with the rest of the country. According to the official statements of the Polish Cycling Federation (PZKol.), the race was organized to "underline the link with the ancient Piast lands", that is Pomorze Zachodnie ("Kurier Szczeciński", 1946, No. 223). This time two Szczecin cyclists managed to take part, but unfortunately, they did not finish the race. The autumn of 1946 brought about the activation of other communities in Pomorze Zachodnie. In the first poviat sport games in Białogard, apart from other competitions, an 18-km race was organized ("Kurier Szczeciński", 1946, No. 223).

Both establishing contacts with PZKol. and, especially, the appropriate infrastructure, resulted in Szczecin being commissioned to build a central training camp for leading Polish athletes, who were preparing for the 1948 Olympic Games in London. Apart from training, fans in Szczecin could also watch the struggles of cyclists participating in track racing. Another large event commissioned to OZKol. in Szczecin was a long-distance race as part of the Polish championship covering the 200-km long Kołobrzeg-Szczecin route ("Kurier Szczeciński", 1947, No. 175). In 1947, cycling units in other sports clubs were also opened. In July, Militia Sports Club from Łobza was accepted as a member of OZKol., while in August, the "Pionier" Railway Sports Club from Szczecin joined the federation. In the autumn of that year, a cycling unit was organized at the "Drukarz" Union Sports Club in Szczecin (APSz, the Voivodship National Council - PWRN in Szczecin, file number 11477, Minutes of meetings of the Regional Cycling Federation, 1946-1949, p. 17). At that time, the leading cyclist of "Pionier" was Kazimierz Broszczak, a dismissed soldier from the $2^{\text {nd }}$ Polish Corps in the West under the command of General Władysław Anders. Arriving from France to Szczecin, he brought with him three new racing bicycles, which were then the only high-performance bicycles in Pomorze Zachodnie. K. Broszczak also won the first official track cycling championships of Szczecin organized on September 7, 1947. All profit from the event, as in many other cases, was dedicated to the reconstruction of Warsaw ("Głos Szczeciński", 1947, No. 85). It was a kind of levy of former German lands incorporated into Poland, intended for rebuilding the capital of Poland from the rubble. This also meant 
that the central authorities were not interested in the rapid development of the Western and Northern territories. Unfortunately, the above-mentioned competition became a source of conflict between the management of OZKol. and the top cyclists who demanded a cash equivalent for taking part in the race. As a result of the conflict, L. Bestry resigned from the post of the president but was reinstated after a year.

The above-mentioned K. Broszczak participated in the Tour de Pologne in 1947 and took the $19^{\text {th }}$ place. In March 1948, he was drafted to the central training camp before the Warsaw-Prague-Warsaw Race, later known as Wyścig Pokoju (the Peace Race) (“Głos Szczeciński”, 1948, No. 76). However, ultimately, he was not qualified for the international competition. In 1948, another great talent appeared in Szczecin - Zygmunt Przezdomski.

When planning the main cycling event in 1948 - the Tour of Poland, the Zachodniopomorskie unit was not omitted. The fourth stage of this event took place between Słupsk and Szczecin, while the next was organized on the Szczecin-Poznań route. Pre-war cyclist Kazimierz Konopczyński, who lived in Szczecin and wanted to compete wearing the colors of the "Odra" club took part in the race. However, he did not finish it due to the lack of spare inner tubes ("Kurier Szczeciński”, 1948, No. 174).

In 1948, local races were more and more often organized both on roads and tracks. However, Szczecin remained the center of the voivodeship thanks to proper infrastructure, and most importantly, passion and engagement shown by a handful of sports activists. Another important factor was the authorities' policies, where sports events were included in the multitude of propaganda actions aimed at integrating the Northern and Western territories with the rest of the country. Unfortunately, the progressing vandalizing of vehicles as well as taxes imposed on the organizers of the competition were not conducive to more frequent contacts with the national leaders. Difficult living conditions in Pomorze Zachodnie and the lack of financial support for outstanding athletes made it impossible for other leading cyclists to move to Szczecin.

The year 1948 brought about organizational dependence of sports communities on state authorities (Pasko, 2012). The seats of regional sports federations were located in the building of the Voivodeship Office for Physical Culture and supervised by the Voivodeship Office of Public Security (APSz, ZMiMRN in Szczecin, file number 246, Regional Cycling Federation in Szczecin, 1948-1951, p. 13). All electoral meetings were overseen by the deputes of the provincial authorities, and at the same time, members of the Polish United Workers' Party (PUWP). Furthermore, the representatives of the communist-dependent organizations were also introduced to individual boards. The situation was similar for the management of the Regional Cycling Federation in Szczecin. Antoni Dałkowski, from the Voivodeship Rural Sport Council, was also included in this body. He was to act as the head of the tourism section in the board of OZKol. (APSz, Provincial Committee - PC PUWP in Szczecin, file number 3466, Resolutions and executive functions of PC PUWP on the Sport, 1949, p. 73). Such enlargement of the OZKol. presidium resulted from the authorities' policy aimed at mass popularization of physical culture, especially in the rural environment. Sports organizations, i.e. the Popular Sports Teams, alongside the corps of the Public Organization of "Service for Poland" ("Służba Polsce") and the circles of the Polish Youth Association, were in fact the stronghold of the authorities that set the stage for the introduction of collectivization of agriculture (socialist economy). As it soon turned out, people from the party did not take part in OZKol.'s work and after some time they were replaced by other activists.

The centralization of sport also had an organizational aspect. Sports federations based on social movements could not simply be registered, and thus were dissolved (Godlewski, 2002). To survive, they joined new units applying the new structure of sport (APSz, PWRN in Szczecin, file number 11535, Minutes of organizational clubs' 
meetings, 1949, p. 100). Since 1950, sports clubs at the workplace and the District Councils of Sports Associations, related to specific trade unions, have been organized (APSz, Marshall Office in Szczecin - UWS, file number 1383 , Associations and Unions, 1949-1950, p. 122). One of the consequences of such policy was the actual mass popularization of physical culture, often forcefully, as well as the fragmentation of the potential of competitive sport. While mass popularization of sport was easy to carry out in large cities, similar activities faced numerous problems in the rural environment. In addition to the lack of trained staff, there was simply a shortage of equipment. Programs and declarations were prepared, but usually had no realistic follow-up ("Kurier Szczeciński”, 1949, No. 50). Moreover, it was easier to attract athletes for political demonstrations, parades on "the holiday of the working class" on May 1 , or "People Holiday" (July 22) than to materially support the development of competitive sport.

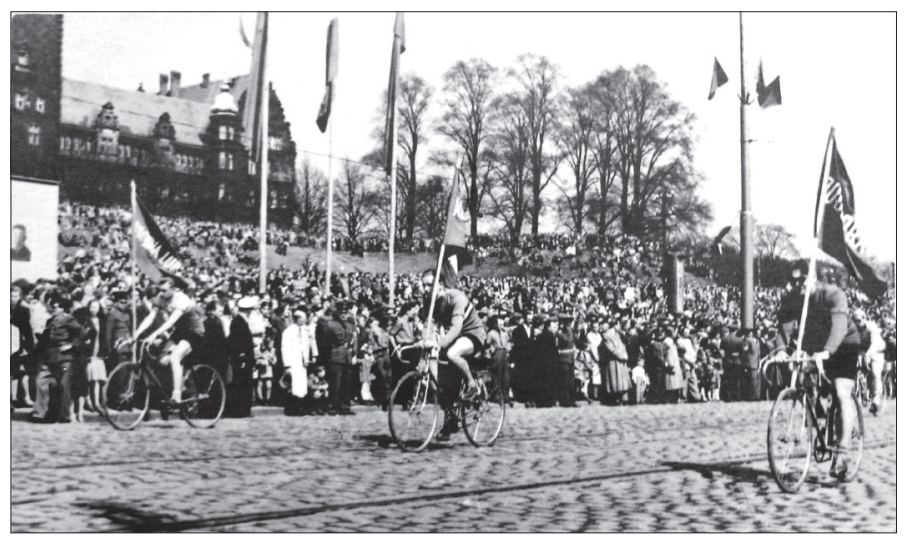

Figure 2. Leading Szczecin cyclists on the March of the 1st May on Wały Chrobrego in Szczecin, beginning of the 1950s Source: Private collections of $Z$. Borowski.

When on 28 September 1949 the Resolution of the Political Bureau of the Central Committee of the Polish United Workers' Party on Physical Culture and Sport modelled on the resolution of the Central Committee of the All-Union Communist Party (Bolsheviks) was promulgated, it was decided that the structure of Polish sport should be based on Soviet patterns. Physical education and sport became an instrument of the authorities in the process of indoctrination of the society and preparation of youth for work and military service (Szymański, 2004).

In Szczecin alone, the years 1949-1950 brought about the organization of a series of cycling events. They were prepared not only for training needs, nationwide classifications, central championships, but also for propagating this sport and attracting youth. Training took place twice a week, and on Sundays there were organized the so-called fitness training, i.e. cycling tours throughout the entire voivodeship. 


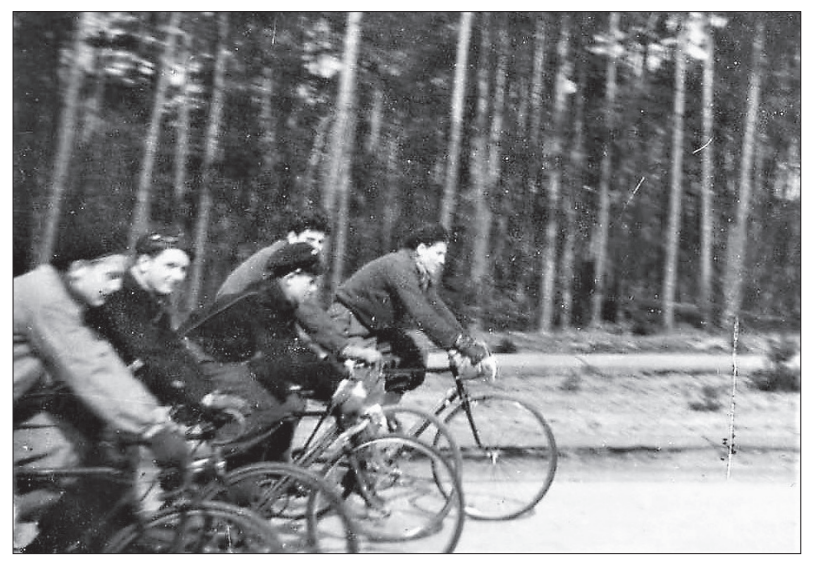

Figure 3. Cycling tour of Szczecin's competitors in 1949

Source: Collections of WKFiZ US.

In 1949, the top cyclists from Szczecin included Kazimierz Broszczak, Tadeusz Janicki, Józef Sołtowski, Zygmunt Przezdomski, Eugeniusz Rotmajer and Zbigniew Borowski. They took part in nationwide competitions, often organized with the purpose of propaganda, and competed against the best athletes in Poland (APSz, PWRN in Szczecin, file number 11477; Protocols of meetings of the Szczecin Regional Cycling Federation, 1946-1949, p. 65). In 1949, K. Broszczak represented Szczecin in the biggest event of the year - the Tour de Pologne, and took the $58^{\text {th }}$ place. On the other hand, the largest cycling event of international character in Szczecin at that time was Poland-Czechoslovakia track cycling competition (June 29, 1949). Although no local cyclist was included in the Polish national team, the race was an exceptional event in Pomorze Zachodnie.

The year 1949 witnessed the first great successes of the rising star from Szczecin - Zygmunt Przezdomski. The opportunity to present his physical prowess was the 3-stage "Brzegiem Bałtyku" ("Along the Baltic shore") road race on the route Gdańsk-Szczecin organized in July. The cyclist won in the third stage and was the winner in the general classification ("Kurier Szczeciński", 1949, No. 202). In addition to the races in the official annual competition schedule, the authorities organized purely propaganda events. Such events included, among others, a seven-day "propaganda-tourist" cycling rally in the territory of Szczecin voivodship (July 21-28, 1949), that was considered a part of the so-called uniting the city with the village. The program of the trip included community service by the participants, demonstration sports events and artistic performances. In the group of amateurs, referred to as tourists, there was a talented junior - Janusz Klabecki, who in later years achieved some considerable successes (APSz, PC PUWP, file number 3466, Resolutions and guidelines of the Executive Committee of the Polish United Workers' Party in sports, 1949, pp. 67-68). Another propaganda event was postman races organized as a competition accompanying the Race around Poland ("Kurier Szczeciński”, 1949, No. 216).

Szczecin community was lucky to have a concrete cycling track, which is why the Polish Championship covering the distance of $50 \mathrm{~km}$ took place in the capital of the voivodeship on August 7, 1949. The race was won by Tadeusz Gabrych ("Włókniarz" Łódź), who came first before Bolesław Napierała (“Ogniwo" Warsaw) and Jan 
Janicki ("Włókniarz" Wrocław). The best cyclist from Szczecin - Kazimierz Broszczak - took the $5^{\text {th }}$ place, and Zygmunt Przezdomski - the $7^{\text {th }}$ ("Głos Szczeciński", 1949, No. 128).

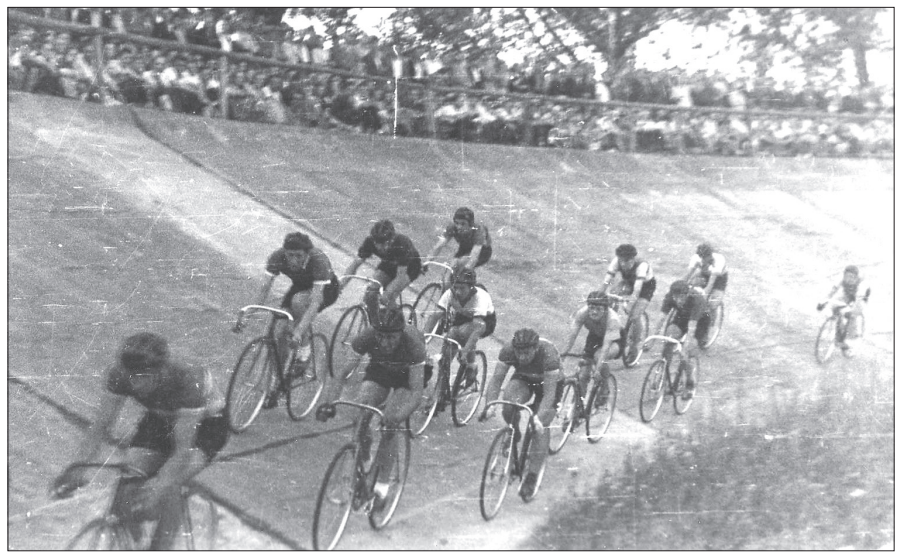

Figure 4. Polish Championships in Szczecin covering the distance of $50 \mathrm{~km}$ in Szczecin in 1949

Source: Collection of WKFiZ.

In 1950, another star of Szczecin cycling appeared - Tadeusz Drążkowski, as well as Bernard Pruski in Stargard near Szczecin. In his first competition, T. Drażkowski participated as a "tourist", i.e. an unassociated athlete, and in the subsequent ones, he represented the People Sports Team from Bezrzecze (the village in the vicinity of Szczecin - currently a district of the city). In September that year, he was moved to the militia club and from that moment he became a member of the "Gwardia" Sports Association in Szczecin.

At that time, the burden of popularizing cycling had to be carried by OZKol., as well as the individual sections of clubs and sports clubs, and the editorial office of the journal Kurier Szczeciński. A cyclical (annual) mass street race for the Editorial Cup was organized. About 200 cyclists took part in its first edition (May 21, 1950) ("Kurier Szczeciński", 1950, No. 140). However, it was not only its mass character that became the hallmark of Szczecin's sport. An extraordinary feature at that time was encouraging women, or rather girls, to start cycling. The program of street competitions organized on the day of the "People Holiday" (July 22, 1950) included open races on the track for non-members. Two women from the "Budowlani" Szczecin club decided to compete in a separate race ("Kurier Szczeciński”, 1950, No. 201).

Until the end of that year, Szczecin cyclists took part in several competitions, both on national routes and tracks as well as in local races. They competed against the top Polish cyclists at nationwide events without any complexes.

\section{Conclusions}

In 1945-1950, cycling in Zachodniopomorskie voivodeship was developing systematically. Its progress depended on the settlement and economic processes, but primarily resulted from the pre-war traditions, personal 
involvement of activists and the growing popularity of sport in the urban environment. The communists gradually, but consistently, started to use sport in the process of indoctrination, i.e. to shape a "politically conscious citizen" who would obey the elites of the PUWP party. Despite these influences, for the majority of activists and athletes, sport remained a great, unique passion and a way of life in the socialist world. Therefore, acts of political manifestation, participation in parades, rallies and propaganda ceremonies were accepted by athletes in return for organizational and financial support.

The year 1950 brought progress in the development of Szczecin cycling. The number of OZKol.'s members visibly increased. The cycling units that operated in Szczecin clubs included "Budowlani", "Gwardia", "Kolejarz", "Ogniwo", "Spójnia" and "Związkowiec". Apart from Szczecin, cycling was being trained in "Spójnia" Stargard, "Ogniwo" Połczyn Zdrój, and "Stal" Słupsk. In the mid-1950s, the administrative reform of the country was carried out. As a result, the area of the voivodship, covering the whole of Pomorze Zachodnie, was divided into two smaller territorial units: Szczecińskie and Koszalińskie voivodeships. The constant development of cycling, however, compensated for these changes, especially since Szczecin was the center of this sport in the voivodship.

Cycling in West Pomerania, drawing from the before war traditions, developed gradually and sports societies had to overcome problems associated with lack of instructors, lack of available sports equipment and the state of infrastructure. Difficult living conditions, which often distracted residents from active participation in sports, also had significant meaning. However social work was supported by the government, which saw in sports the tools for integrating settlers and whole West Pomerania with the rest of the country as well as the propaganda impact on the population. The taken care by the state over the competitive sports and growing popularity of cycling contributed to systematic development of the said discipline in the concerned region, despite the marginalization of West Pomerania by the central power center.

In the first half of the fifties of the $20^{\text {th }}$ century the work of Szczecin society promoted first cyclists who started to achieve successes in domestic and international competitions.

\section{Referennces}

\section{Archives}

APSz, Marshall Office in Szczecin - UWS, file number 1383, Associations and Unions, 1949-1950.

APSz, Provincial Committee - PC PUWP in Szczecin, file number 3466, Resolutions and executive functions of PC PUWP on the Sport, 1949.

APSz, PWRN in Szczecin, file number 11535, Minutes of organizational clubs' meetings, 1949.

APSz, the Voivodship National Council - PWRN in Szczecin, file number 11477, Minutes of meetings of the Regional Cycling Federation, 1946-1949.

APSz, ZMiMRN in Szczecin, file number 246, Regional Cycling Federation in Szczecin, 1948-1951.

APSz, ZMiMRN in Szczecin, file number 520, Report on the activities of the City Committee of Physical Education and Military Training in Szczecin.

The State Archive in Szczecin - APSz, the City Board and National City Council - ZMiMRN in Szczecin, file number 240, "Odra" Sports Club, 1945-1949.

\section{Press}

"Głos Szczeciński" (1947-1950).

"Kurier Szczeciński” (1945-1950). 


\section{Literature}

Godlewski, P. (2002). Sowietyzacja sportu w Polsce (lata 1948-1956). In: T. Jurek (ed.), Studia z dziejów kultury fizycznej (pp. 441455). Gorzów Wlkp.: PTNKF.

Pasko, A. (2012). Sport wyczynowy w polityce państwa 1944-1989. Kraków: AVALON.

Szymański, L. (2004). Kultura fizyczna i turystyka w polityce Polski Ludowej 1944-1989. Wrocław: AWF Wrocław.

Tuszyński, B. (1986). 100 lat Warszawskiego Towarzystwa Cyklistów, 100 lat kolarstwa polskiego. Warszawa.

Cite this apticle aS: Stefanik, R., Zawadzki, M. (2020). Social and Political Aspects of the Development of Cycling in Pomorze Zachodnie (West Pomerania) in the Years 1945-1950. Central European Journal of Sport Sciences and Medicine, 2 (30), 5-14. DOI: $10.18276 /$ cej.2020.2-01. 